\title{
Analysis of phosphatases in ER-negative breast cancers identifies DUSP4 as a critical regulator of growth and invasion
}

\author{
Abhijit Mazumdar $^{1} \cdot$ Graham M. Poage $^{1} \cdot$ Jonathan Shepherd $^{1} \cdot$ Anna Tsimelzon $^{2}$. \\ Zachary C. Hartman ${ }^{1}$ - Petra Den Hollander ${ }^{1} \cdot$ Jamal Hill $^{1} \cdot$ Yun Zhang $^{1}$ • \\ Jenny Chang ${ }^{3}$ - Susan G. Hilsenbeck ${ }^{2}$ Suzanne Fuqua ${ }^{2}$ - C. Kent Osborne ${ }^{2}$. \\ Gordon B. Mills ${ }^{4} \cdot$ Powel H. Brown ${ }^{1}$
}

Received: 28 January 2016/ Accepted: 27 June 2016/Published online: 8 July 2016

(C) The Author(s) 2016. This article is published with open access at Springerlink.com

\begin{abstract}
Estrogen receptor (ER)-negative cancers have a poor prognosis, and few targeted therapies are available for their treatment. Our previous analyses have identified potential kinase targets critical for the growth of ER-negative, progesterone receptor (PR)-negative and HER2negative, or "triple-negative" breast cancer (TNBC). Because phosphatases regulate the function of kinase signaling pathways, in this study, we investigated whether phosphatases are also differentially expressed in ER-negative compared to those in ER-positive breast cancers. We compared RNA expression in 98 human breast cancers (56 ER-positive and 42 ER-negative) to identify phosphatases differentially expressed in ER-negative compared to those in ER-positive breast cancers. We then examined the effects of one selected phosphatase, dual specificity phosphatase 4 (DUSP4), on proliferation, cell growth, migration and invasion, and on signaling pathways using protein microarray analyses of 172 proteins, including
\end{abstract}

Electronic supplementary material The online version of this article (doi:10.1007/s10549-016-3892-y) contains supplementary material, which is available to authorized users.

Powel H. Brown

phbrown@mdanderson.org

1 Department of Clinical Cancer Prevention, The University of Texas M.D. Anderson Cancer Center, Houston, TX 77030, USA

2 Department of Medicine and the Dan L. Duncan Cancer Center, Lester and Sue Smith Breast Center, Baylor College of Medicine, Houston, USA

3 Methodist Cancer Center, The Methodist Hospital Research Institute, Houston, USA

4 Department of Systems Biology, The University of Texas M.D. Anderson Cancer Center, Houston, USA phosphoproteins. We identified 48 phosphatase genes are significantly differentially expressed in ER-negative compared to those in ER-positive breast tumors. We discovered that 31 phosphatases were more highly expressed, while 11 were underexpressed specifically in ER-negative breast cancers. The DUSP4 gene is underexpressed in ER-negative breast cancer and is deleted in approximately $50 \%$ of breast cancers. Induced DUSP4 expression suppresses both in vitro and in vivo growths of breast cancer cells. Our studies show that induced DUSP4 expression blocks the cell cycle at the G1/S checkpoint; inhibits ERK1/2, p38, JNK1, RB, and NFkB p65 phosphorylation; and inhibits invasiveness of TNBC cells. These results suggest that that DUSP4 is a critical regulator of the growth and invasion of triple-negative breast cancer cells.

Keywords TNBC Phosphatase $\cdot$ Mouse xenograft . MAPK pathways

\section{Introduction}

Breast cancer is the most frequently diagnosed cancer in women and the second highest cause of cancer-related death in United States women in 2016 [1]. Selective estrogen receptor modulators (SERMs) and aromatase inhibitors are currently used to treat ER-positive breast cancers [2-6], while anti-HER2 drugs are used to treat ERnegative HER2-positive breast cancers [7-9]. However, there are few treatment options available for breast cancers that do not express ER, progesterone receptor (PR), or the HER2 protein, otherwise known as "triple-negative" breast cancers (TNBCs). As no targeted therapy is available for most TNBC tumors, cytotoxic chemotherapy is the current treatment strategy. 
We previously conducted cDNA microarray studies to identify potential therapeutic targets of ER-negative breast cancers [10]. These studies identified several kinases critical for the growth of TNBC. In this study, we sought to identify phosphatases differentially expressed in ER-negative tumors that also regulate breast cancer growth. We identified 11 underexpressed and 31 overexpressed phosphatases in ER-negative compared to those in ER-positive breast cancers. We initially focused on those 11 phosphatases underexpressed exhibiting decreased expression in ER-negative tumors and found that of these 11 underexpressed phosphatases, DUSP4 is the most frequently deleted phosphatase in ER-negative breast cancer.

DUSP4 specifically regulates extracellular regulated kinase (ERK), and the phosphatase activity of DUSP4 is enhanced upon interaction with ERK and p38 [11-13]. DUSP4 expression has been shown to play an important role in senescence [14] and emerging evidence suggests DUSP4 is involved in the growth and progression of cancer $[15,16]$. Our results demonstrate that DUSP4 is frequently deleted in breast cancer and underexpressed in TNBCs, and that DUSP4 overexpression halts TNBC tumor growth and invasion. Our results also demonstrate that all three MAPK proteins (ERK1/2, p38, and JNK1) are negatively regulated by DUSP4. Moreover, re-expression of DUSP4 also inhibits other growth inducing pathways, including $\mathrm{NF \kappa B}$ and $\mathrm{Rb}$. Overall, this study demonstrates that DUSP4 is frequently deleted in breast cancers and is a critical regulator of growth and invasion of TNBCs, suggesting DUSP4 is an important tumor suppressor gene in these aggressive breast cancers.

\section{Materials and methods}

\section{Breast tumor and microarray datasets}

All tumors were collected by Dr. Jenny Chang and approved by the institutional review board of Baylor College of Medicine. This tumor set, including tumor stage, size, and patient race and menopausal status, has been previously described [10]. In this study, four samples were removed from the analysis. These four samples had an unconfirmed ER status or appeared as outliers on the principal component analysis (PCA) plot and thus removed from the dataset. Therefore, 98 samples, 56 ER-positive and 42 ER-negative invasive breast cancers, were used for this analysis. Gene expression was estimated using the Robust Multi-array Average (RMA) procedure. We limited our data and clustering analysis to 262 genes (454 probesets on Affymetrix U133A chip), which encode known phosphatases and proteins with phosphatase in their name. We used the most variable probeset for each of the 262 genes. Statistical analysis was done using Partek software (http://partek.com). The following criteria were used to find genes differentially expressed between ER-negative and ER-positive tumors: Benjamini-Hochberg false discovery rate $(\mathrm{FDR}) \quad p$ value $\leq 0.1$, fold change $\geq 1.2$ or $\leq 0.8$.

\section{Cell lines and cell culture}

The MCF-7 (HTB-22), MDA-MB-231 (HTB-26), and MDA-MB-468 (HTB-132) cell lines (American Type Culture Collection (ATCC), Manassas, VA, USA) were cultured in DMEM (Cellgro by Mediatech, Inc., Manassas, VA, USA) supplemented with $10 \%$ fetal bovine serum, $100 \mathrm{U} / \mathrm{ml}$ penicillin, and $100 \mathrm{mg} / \mathrm{ml}$ streptomycin. These were grown and maintained as described in Supplementary Methods. STR profiles were compared to (1) known ATCC fingerprints (ATCC.org); (2) the Cell Line Integrated Molecular Authentication database (CLIMA) version 0.1.200808 (http://bioinformatics.istge.it/clima/) [17]; and (3) the MD Anderson fingerprint database.

\section{Reagents and antibodies}

The DUSP4 antibody was purchased from BD Transduction Laboratories (Lexington, KY, USA). Phospho-ERK1/2 (\#4370) and total ERK1/2 (\#4372) were purchased from Cell Signaling Technology, Inc. (Danvers, MA, USA). Antiactin antibody was purchased from Sigma-Aldrich Corp. (St. Louis, MO, USA). Antimouse (\#NA931 V) and antirabbit (NA934 V) secondary antibodies were obtained from GE Healthcare Bio-sciences Corp. (Piscataway, NJ, USA).

\section{Viral vectors and modification of cell lines}

The DUSP4 ORF clone was obtained from Open Biosystems (Huntsville, AL, USA) and cloned into tetracycline (Tet)inducible vector (pTIPZ) through a gateway LR clonase reaction. Final constructs were verified through restriction digestion and sequencing. Lentiviral vectors were prepared as described previously [18]. Stable cell lines expressing inducible cDNAs were generated by lentiviral infection using a pTIPZ lentiviral expression system in the presence of $4 \mu \mathrm{g} / \mathrm{ml}$ polybrene, followed by puromycin selection at $48 \mathrm{~h}$ post infection. All pTIPZ stable cell lines were maintained in media with Tet-safe serum (Clontech Laboratories Inc., Mountain View, CA, USA).

\section{Quantitative RT-PCR (qRT-PCR) assessments}

Quantitative PCR assays of reverse-transcribed transcripts (4 replicates per transcript) were carried out using an ABI 
PRISM 7900 Sequence Detection System (Life Technologies (formerly Applied Biosystems Inc., Foster City, CA, USA), as previously described [10].

\section{Cell growth assays}

Cellular proliferation and anchorage-independent growth were measured as described previously [19].

\section{Cell cycle assays}

To measure cell cycle distribution, Tet-inducible cells were treated for 4 days with or without doxycycline $(2 \mu \mathrm{g} / \mathrm{ml})$ to induce DUSP4 gene expression. Cells were then harvested and fixed overnight in $70 \%$ ethanol at $-20{ }^{\circ} \mathrm{C}$. Cells were then stained with propidium iodide (PI) $(1 \mu \mathrm{g} / \mathrm{ml})$ in $0.1 \%$ Triton $\mathrm{X}-100$ and RNase in PBS and analyzed using a FACSCalibur Flow Cytometer (BD Biosciences, Franklin Lakes, NJ, USA).

\section{Western blot analysis}

Western blot analyses were performed as described previously [19]. Antibodies used include anti-DUSP4 antibody (BD Biosciences, San Jose, CA, 1:1000), anti-phosphoERK1/2 antibody (1:1000), and anti-ERK1/2 (1:1000) (both from Cell Signaling Technology Inc., Danvers, MA, USA). Anti-Vinculin antibody (Sigma-Aldrich Corp., St. Louis, MO, USA) was used at a 1:2000 dilution.

\section{Boyden chamber invasion assay}

Matrigel-coated transwell cell culture chambers (BD Transduction Laboratory, Lexington, KY, USA) and inserts of $8 \mu \mathrm{m}$ pore size (Corning Inc. Life Sciences, Lowell, MA, USA) were used to measure invasion of TIPZ-DUSP4 in MDA-MB-231 and SUM 159 cells. $3 \times 10^{5}$ cells/well were placed in the upper chamber of the transwell inserts in serum-free media. Media containing $10 \% \mathrm{FBS}$ was placed in the lower chambers. All samples were incubated for $20 \mathrm{~h}$ at $37{ }^{\circ} \mathrm{C}$ in a humidified atmosphere with $5 \% \mathrm{CO}_{2}$. Noninvasive cells in the upper chambers were removed by cotton swab. Invasive cells were then fixed and stained with HEMA3 (Fisher Scientific Company, LLC, Kalamazoo, MI, USA). Invasive cells on the lower surface of the filters which penetrated through the Matrigel were then mounted on glass slides, counted, and photographed using a light microscope at $\times 40$ magnification. Migration assays were performed using transwell inserts without Matrigel. Percent invasion was calculated based on number of cells invaded divided by number of cells migrated, and the results were multiplied by 100 . All assays were performed in triplicate and the results shown as average \pm standard deviation.

\section{Reverse phase protein array (RPPA)}

RPPA assays were performed in the MD Anderson Core facility. Experimental details are provided in Supplementary Materials.

\section{Mouse experiments}

Experiments using nude mice (The Jackson Laboratory, Bar Harbor, ME, USA) were performed in accordance with M.D. Anderson Institutional Animal Care and Use Committee (IACUC)-approved protocols. Experimental details of our mouse experiments are provided in Supplementary Materials.

\section{Results}

\section{Identification of phosphatases differentially expressed in ER-negative breast cancer}

To identify phosphatases differentially expressed in ERnegative breast cancers, we compared RNA levels in ERpositive and ER-negative human breast cancer samples using a strategy analogous to our previous exploration of kinase expression [10]. Tumor samples from 98 invasive breast cancer patients (56 ER-positive, 42 ER-negative) were previously classified as ER positive or ER negative using IHC staining for ER $\alpha$ [10]. RNA expression in ERpositive and ER-negative breast tumors was then analyzed by Affymetrix gene expression profiling to identify molecules differentially expressed in ER-negative breast cancer compared to those in ER-positive breast cancers. We identified 31 overexpressed (fold $\geq 1.2$, FDR-adjusted $p \leq 0.1) \quad$ and 11 underexpressed phosphatases (fold $\leq 0.80$, adjusted $p \leq 0.1$ ) in ER-negative tumors compared to those in ER-positive tumors (Table 1; Fig. 1a). Figure 1b shows the hierarchical clustering seen when only ER-negative tumors are clustered using the differentially expressed genes identified in Fig. 1a. Through these analyses, we identified several phosphatases critical to cell signaling and metabolic pathways in both the over- and underexpressed phosphatase groups, including overexpressed phosphatases that regulate kinases and cell cycle progression (CDC25A, CDC25B, and CDKN3), and underexpressed phosphatases that regulate the MAPK and PI3 K pathways (INPP4B, DUSP4, and DUSP11).

Focusing on phosphatases underexpressed in ER-negative breast cancer, we next investigated whether these differentially expressed genes were homogeneously expressed in ER-negative tumors. As shown in Fig. 1b, these genes are differentially expressed in ER-negative tumors. The entire ER-negative group is divided into three 
Table 1 Differential expression of overexpressed phosphatases in ER-negative versus ER-positive breast cancer

\begin{tabular}{|c|c|c|c|}
\hline Gene name & Symbol & Fold & $\begin{array}{l}\text { Adjusted } \\
p \text { value }^{\mathrm{a}}\end{array}$ \\
\hline \multicolumn{4}{|l|}{ Overexpressed phosphatases $(\geq 1.2$-fold, $p<0.1)$} \\
\hline Inositol(myo)-1(or 4)-monophosphatase 2 & IMPA2 & 1.87 & 0.0006 \\
\hline Lipin 1 & LPIN1 & 1.85 & 0.0000 \\
\hline Protein tyrosine phosphatase-like (proline instead of catalytic arginine), member A & PTPLA & 1.84 & 0.0002 \\
\hline Discs, large (Drosophila) homolog-associated protein 5 & DLGAP5 & 1.84 & 0.0004 \\
\hline Pyruvate dehydrogenase phosphatase catalytic subunit 1 & PDP1 & 1.62 & 0.0009 \\
\hline Acid phosphatase 1 , soluble & $\mathrm{ACP} 1$ & 1.56 & 0.0002 \\
\hline Protein tyrosine phosphatase, receptor-type, $\mathrm{Z}$ polypeptide 1 & PTPRZ1 & 1.51 & 0.0073 \\
\hline Protein tyrosine phosphatase, receptor type, $\mathrm{K}$ & PTPRK & 1.48 & 0.0239 \\
\hline Protein tyrosine phosphatase, receptor type, C & PTPRC & 1.46 & 0.0956 \\
\hline Chromosome 12 open reading frame 5 & C12orf5 & 1.43 & 0.0038 \\
\hline Protein phosphatase 3 , regulatory subunit $\mathrm{B}$, alpha & PPP3R1 & 1.36 & 0.0000 \\
\hline Pyrophosphatase (inorganic) 1 & PPA1 & 1.36 & 0.0105 \\
\hline Protein phosphatase 1 , catalytic subunit, beta isozyme & PPP1CB & 1.34 & 0.0003 \\
\hline Cyclin-dependent kinase inhibitor 3 & CDKN3 & 1.32 & 0.0508 \\
\hline Protein tyrosine phosphatase-like (proline instead of catalytic arginine), member B & PTPLB & 1.28 & 0.0652 \\
\hline Cell division cycle 25B & $\mathrm{CDC} 25 \mathrm{~B}$ & 1.27 & 0.0723 \\
\hline Protein tyrosine phosphatase, nonreceptor type 2 & PTPN2 & 1.26 & 0.0067 \\
\hline Cell division cycle 14B & CDC14B & 1.25 & 0.0531 \\
\hline Signal-regulatory protein alpha & SIRPA & 1.25 & 0.0195 \\
\hline Protein phosphatase 2, regulatory subunit B', alpha & PPP2R3A & 1.24 & 0.0227 \\
\hline Protein tyrosine phosphatase, receptor type, $\mathrm{F}$ & PTPRF & 1.24 & 0.0723 \\
\hline Myotubularin-related protein 2 & MTMR2 & 1.23 & 0.0337 \\
\hline Nudix (nucleoside diphosphate linked moiety X)-type motif 15 & NUDT15 & 1.23 & 0.0358 \\
\hline Cell division cycle $25 \mathrm{~A}$ & $\mathrm{CDC} 25 \mathrm{~A}$ & 1.23 & 0.0227 \\
\hline Cytochrome c, somatic & CYCS & 1.22 & 0.0837 \\
\hline Dual specificity phosphatase 11 (RNA/RNP complex 1-interacting) & DUSP11 & 1.21 & 0.0358 \\
\hline Nudix (nucleoside diphosphate linked moiety $\mathrm{X}$ )-type motif 1 & NUDT1 & 1.21 & 0.0780 \\
\hline Inositol monophosphatase domain containing 1 & IMPAD1 & 1.20 & 0.0027 \\
\hline Protein tyrosine phosphatase, nonreceptor type 4 (megakaryocyte) & PTPN4 & 1.20 & 0.0227 \\
\hline Protein tyrosine phosphatase, nonreceptor type 22 (lymphoid) & PTPN22 & 1.20 & 0.0024 \\
\hline \multicolumn{4}{|l|}{ Underexpressed phosphatases $(\leq 0.80$-fold, $p<0.1)$} \\
\hline Protein phosphatase 1 , regulatory subunit $3 \mathrm{C}$ & PPP1R3C & 0.46 & 0.0001 \\
\hline Dual specificity phosphatase 4 & DUSP4 & 0.47 & 0.0052 \\
\hline Ectonucleotide pyrophosphatase/phosphodiesterase 1 & ENPP1 & 0.47 & 0.0000 \\
\hline Inositol polyphosphate-4-phosphatase, type II, $105 \mathrm{kDa}$ & INPP4B & 0.48 & 0.0001 \\
\hline Cartilage intermediate layer protein, nucleotide pyrophosphohydrolase & CILP & 0.52 & 0.0001 \\
\hline Fructose-1,6-bisphosphatase 1 & FBP1 & 0.58 & 0.0001 \\
\hline Protein tyrosine phosphatase, receptor type, $T$ & PTPRT & 0.71 & 0.0001 \\
\hline Myotubularin-related protein 9 & MTMR9 & 0.75 & 0.0064 \\
\hline Protein tyrosine phosphatase, receptor type, G & PTPRG & 0.75 & 0.0011 \\
\hline Calcium activated nucleotidase 1 & CANT1 & 0.76 & 0.0931 \\
\hline Inositol polyphosphate-5-phosphatase $\mathrm{J}$ & INPP5 J & 0.80 & 0.0006 \\
\hline
\end{tabular}

${ }^{a}$ FDR adjustment based on 262 features analyzed

major subgroups that express different sets of phosphatases: TNBC, mixed TNBC+Her2, and predominantly Her2-positive tumors. We identified six sets of phosphatases differentially expressed in ER-negative tumors, including one set of underexpressed and one set of overexpressed phosphatases for each of the ER-negative 
Fig. 1 Phosphatases

differentially expressed in ER-

negative and ER-positive breast cancers. a Supervised

hierarchical clustering of breast cancers based on phosphatase expression that distinguishes ER-positive from ER-negative breast tumors. Clinical parameters (HER2, ER, Pam50) are annotated for the samples ( $x$-axis), and gene signature is annotated for the genes ( $y$-axis). b Hierarchical clustering analysis of only ER-negative breast tumors using the phosphatases genes (as shown) selected in $\mathbf{a}$
A

All breast tumors

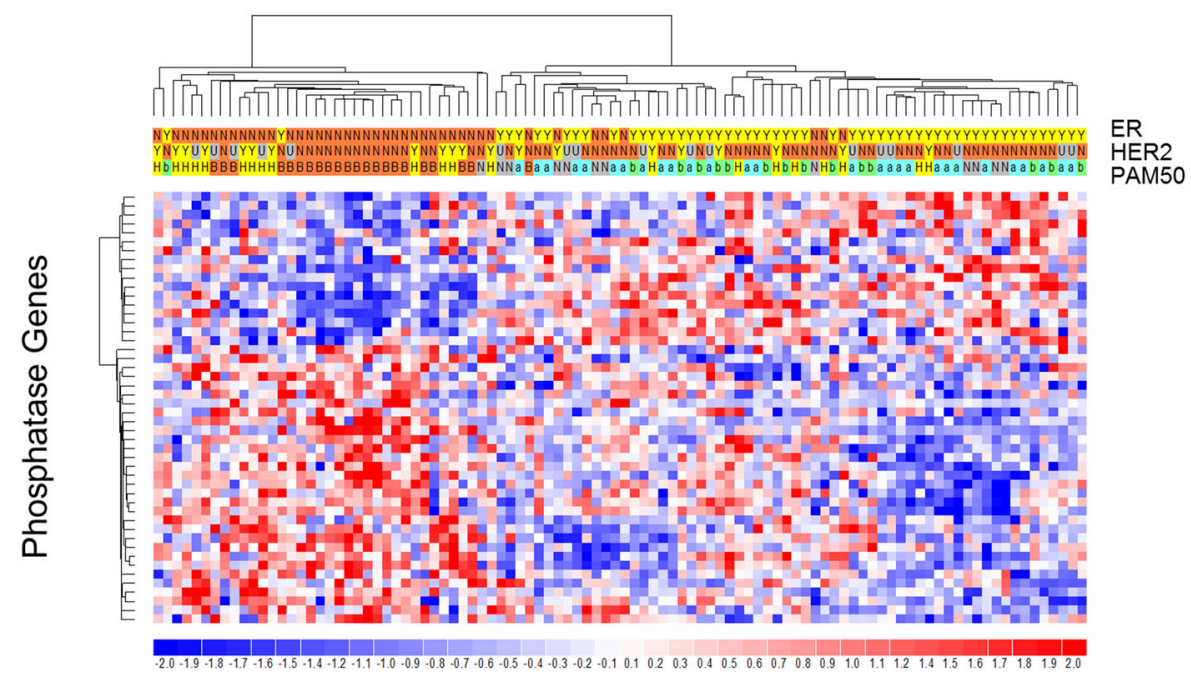

B ER-negative breast tumors

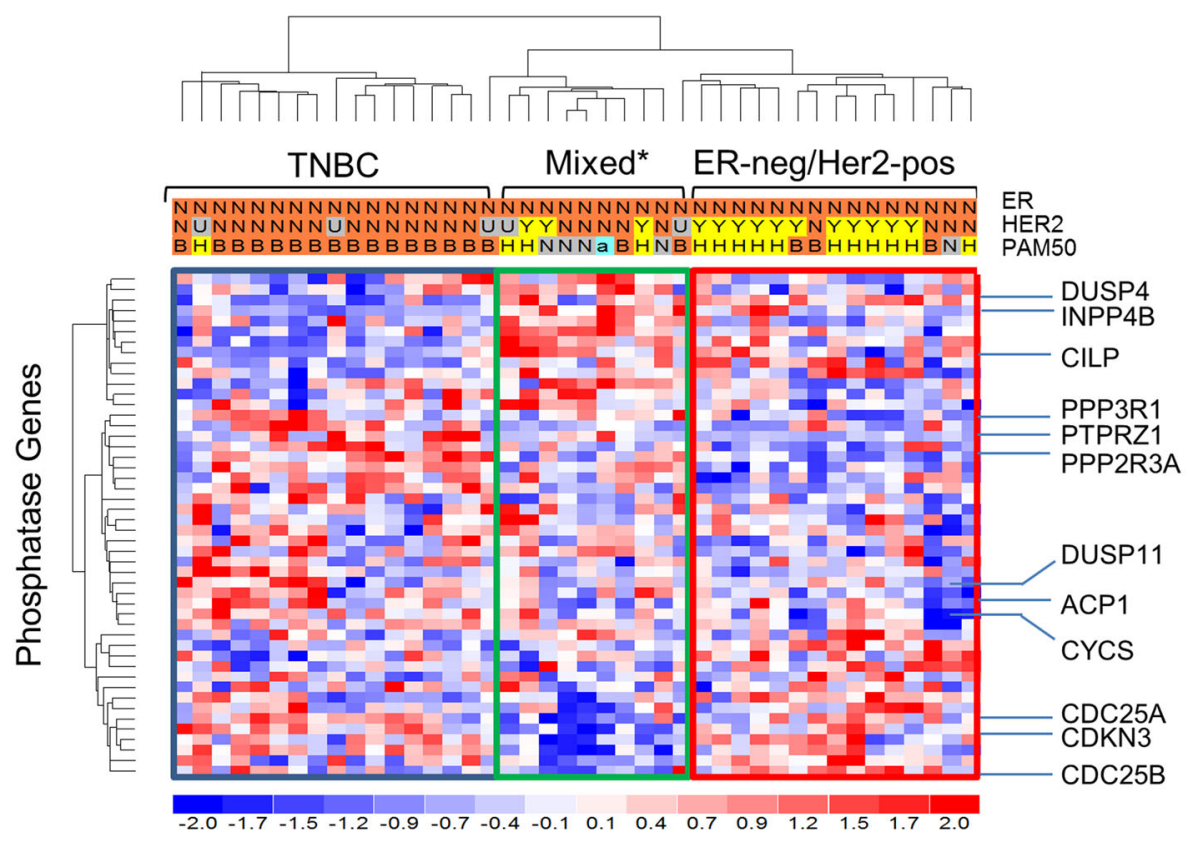

Footnotes: *Mixed = TNBC; ER-neg/Her2-pos.

Abbreviations: ER \& Her2 Banner: $Y=Y e s ; N=N o ; U=$ unknown. PAM50 Banner: $a=$ Luminal $A ; b=$ Luminal $B ; B=$ Basal; $H=$ Her2; $N=$ Normal. subgroups (TNBC, mixed TNBC+Her2, and Her2-enriched) (Supplementary Table 1). One set of phosphatases, which includes INPP4B, DUSP4, and CILP, is underexpressed in the TNBC subgroup compared to that in the other 2 ER-negative subgroups, while another set, which includes PPP3R1, PTPLA, and PTPRZ1, is overexpressed in the TNBC subgroup compared to that in the other two subgroups. A third set of phosphatases, which includes CDC25B, NUDT1, and DLGAP5, is overexpressed in the Her2-enriched subgroup compared to that in the other subgroups (Supplementary Table 1).

We next examined the Breast Invasive Carcinoma TCGA dataset (accessed through the cBioPortal for Cancer Genomics on 01/15/2014) with the genetic alteration 
parameters to include both homozygous deletion and heterozygous loss [20, 21]. We found that among the 5 phosphatases most underexpressed in ER-negative tumors, DUSP4 was the only phosphatase with high-frequency allele loss (Fig. 2a) and exhibited the highest degree of homozygous deletion (Fig. 2b). DUSP4 is frequently somatically altered $(66.6 \%)$ in breast cancers in the TCGA dataset with high proportions of hetero (46.6\%)- and homozygous deletion (5.3\%) (Fig. 2c). In addition to gene loss, copy number gain (14\%), mRMA upregulation $(3.0 \%)$, and amplification $(0.83 \%)$ also occur. We also analyzed DUSP4 somatic alterations in both ER-negative and TNBC populations (Supplementary Figure 1). For this reason, we selected DUSP4 for further study. We next conducted an examination of DUSP4 expression across 10 independent publically available breast cancer microarray datasets (Supplementary Table 3) [22-31]. We selected datasets with $>100$ patients which displayed differential DUSP4 expression in ER-positive versus ER-negative breast cancers $(p<0.001)$. Differential expression of DUSP4 was observed in all 10 datasets (two are shown in Fig. 2d).
Fig. 2 Genomic alteration and expression of phosphatases. a Percent of all tumors with any deletion among the top five underexpressed genes in the TCGA dataset. b Homozygous deletion of selected phosphatases in TCGA. c All somatic alterations of DUSP4 gene represented by the cBio Oncoprint. d Differential expression of DUSP4 in two breast cancer datasets
A

\section{Allelic Deletion in TCGA Breast (All Tumors) \\ Homozygous Deletion in DUSP4 in TCGA Breast (All Tumors)}

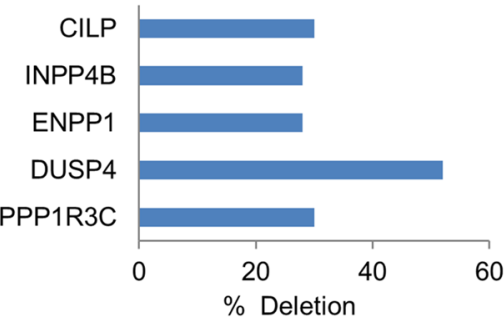

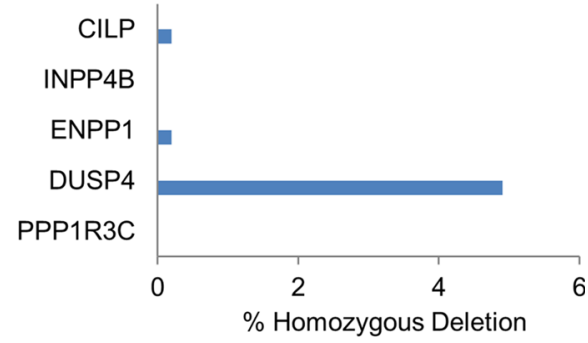

C

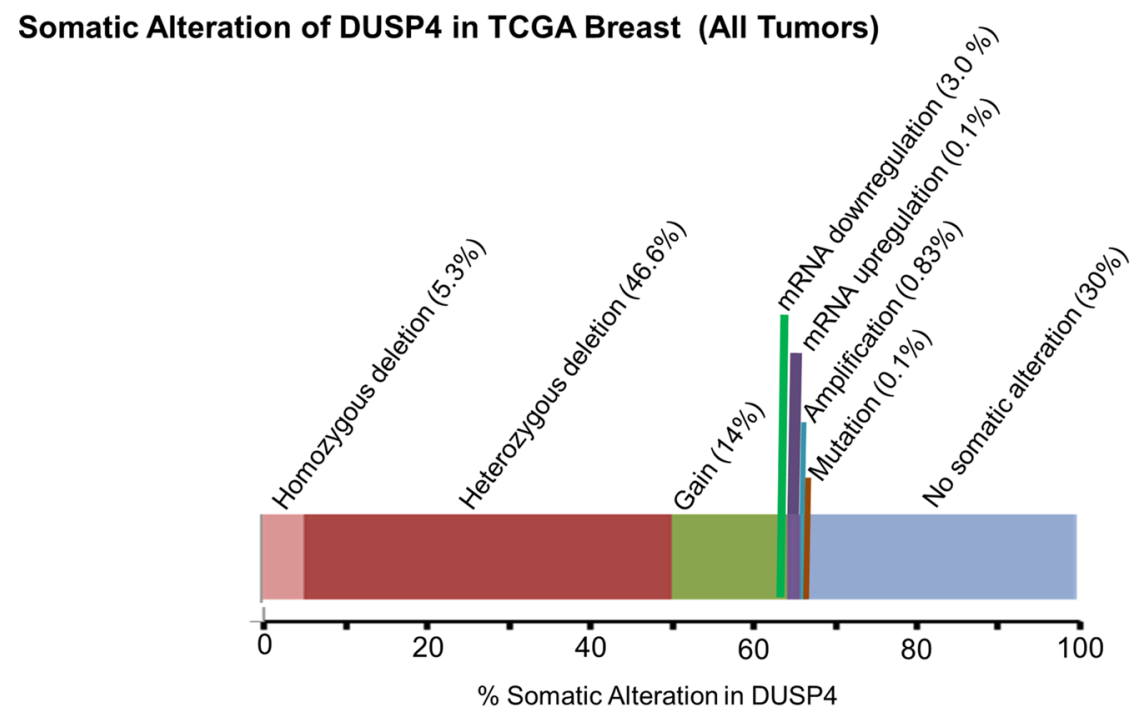

DUSP4 Expression
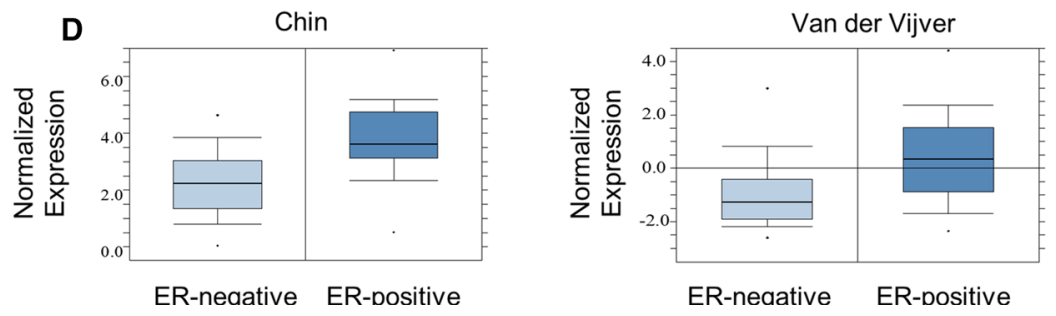
Inducible expression of DUSP4 inhibits ER-negative but not ER-positive breast cancer cell growth in vitro

To determine the role of DUSP4 in regulating growth of ER-negative breast cancer cells, we cloned the DUSP4 into a tetracycline (Tet)-inducible vector (pTIPZ). Lentiviral particles containing pTIPZ-DUSP4 or pTIPZ-vector were infected and stable pools of ER-negative (SUM 159, MDAMB-231) and ER-positive (MCF-7) cell lines were generated by puromycin selection for doxycycline-inducible DUSP4 expression. After 4 days of doxycycline induction, DUSP4 expression was determined by Western blot using anti-DUSP4 antibody. Our results show that after 4 days of doxycycline treatment, DUSP4 expression was significantly induced in all three cell lines (Fig. 3a).

We then determined the effect of DUSP4 on breast cancer cell growth with and without doxycycline using the trypan blue exclusion assay. Our results show that induced DUSP4 expression strongly suppresses cell growth in DUSP4-transfected ER-negative cell lines (SUM159: $89 \%$ repression; MDA-MB-231: $83 \%$ repression), but not in DUSP4-transfected MCF7 ER-positive breast cancer cells (Fig. 3b-d, respectively). Conversely, no detectable change in cell growth rate is associated with doxycycline treatment in any of the vector-transfected cells. Collectively, these results demonstrate induction of DUSP4 inhibits proliferation of ER-negative but not ER-positive breast cancer cells.

\section{Induction of DUSP4 inhibits anchorage-independent growth of ER-negative but not ER-positive breast cancer cells}

We next investigated whether DUSP4 regulates anchorageindependent growth of ER-negative and ER-positive breast cancer cells using the doxycycline-inducible cell lines described above. Our results show induced DUSP4 expression significantly suppresses anchorage-independent growth of DUSP4-transfected ER-negative cells (SUM 159: $95 \%$ suppression; MDA-MB-231: $85 \%$ suppression), but not DUSP4-transfected MCF7 ER-positive cells (Fig. 3e-g, respectively). Vector clones show no change in anchorage-independent growth when treated with doxycycline. These results further demonstrate that DUSP4 induction inhibits growth of ER-negative but not ER-positive breast cancer cells.

\section{Induction of DUSP4 inhibits ER-negative breast cancer growth in vivo}

We next investigated whether DUSP4 expression inhibits in vivo growth of TNBCs using nude and SCID mouse models. After injected cell lines grew into tumors approximately $50 \mathrm{~mm}^{3}$ in volume, mice were randomized to receive either doxycycline-treated or nondoxycyclinetreated water. Growth rate of MDA-MB-231 vector clones was not affected by doxycycline treatment (Fig. 4a). However, strong suppression of tumor growth was associated with doxycycline-induced DUSP4 expression in MDA-MB-231 xenografts compared to nondoxycycline treatment (Fig. 4c). Furthermore, while no difference in growth rate (slope) was observed in MDA-MB-231-vector control clones (Fig. 4b), there was a significant difference in MDA-MB-231-DUSP4 clone growth rates depending on the presence and absence of doxycycline $(p=0.03)$ (Fig. 4d). Significant differences in tumor growth were also observed in inducible SUM159-DUSP4 clones implanted into the mammary fat pad of SCID mice in the presence or absence of doxycycline, but not in SUM159-vector clones (Fig. 4e, g). Similarly, while no difference was apparent in the growth rate of SUM159-vector control clones, there was a significant difference in the SUM 159-DUSP4 clone growth rates in the presence and absence of doxycycline ( $p=0.0002$ ) (Fig. 4f, h). As shown in Fig. 5a, b, Ki67 expression in MDA-MB-231 tumors (measured by immunohistochemistry) was significantly reduced in the DUSP4-transfected group treated with doxycycline $(p=0.004)$. These results are consistent with our in vitro studies and demonstrate that DUSP4 induction inhibits the growth of ER-negative breast tumors in vivo.

\section{Induction of DUSP4 inhibits invasion and causes a cell cycle block}

We next investigated the invasive potential of ER-negative breast cancers before and after DUSP4 induction, and the effect of DUSP4 overexpression on cell motility. Our data show that DUSP4 induction slightly reduces migration of ER-negative breast cancer cells $(p=0.002)$ (Fig. 5c, d) and inhibits the invasiveness of MDA-MB-231 breast cancer cells (Fig. 5e, f) $(p=0.00001)$. We then studied the effect of DUSP4 on the cell cycle using flow cytometry analysis and PI staining. Our results show that DUSP4 expression increases the proportion of cells in G0/G1 ( $p=0.01$ ) and reduces the $\mathrm{G} 2 / \mathrm{M}$ population (Fig. $5 \mathrm{~g}$ ), suggesting that a DUSP4-induced cell cycle blockade is one of the mechanisms preventing growth of ER-negative breast cancer cells.

\section{Induced expression of DUSP4 inhibits the activation of multiple signaling pathways}

We next conducted RPPA protein microarray analyses of 172 proteins before and after DUSP4 overexpression to determine the effects of DUSP4 on these proteins in ER- 
Fig. 3 Induced expression of DUSP4 inhibits ER-negative but not ER-positive growth in vitro. a Western blot analysis of doxycycline-induced expression of DUSP4 in SUM159, MDA-MB-231, and MCF7 breast cancer cells. b-d Proliferation analysis of breast cancer cell lines upon expression of DUSP4.

e-g Anchorage-independent colony formation assay of breast cancer cell lines upon expression of DUSP4

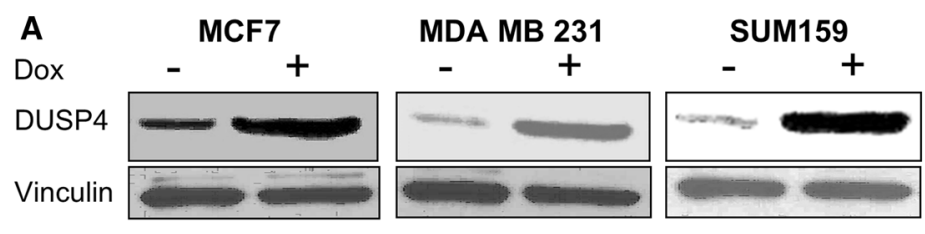

Anchorage-dependent Growth
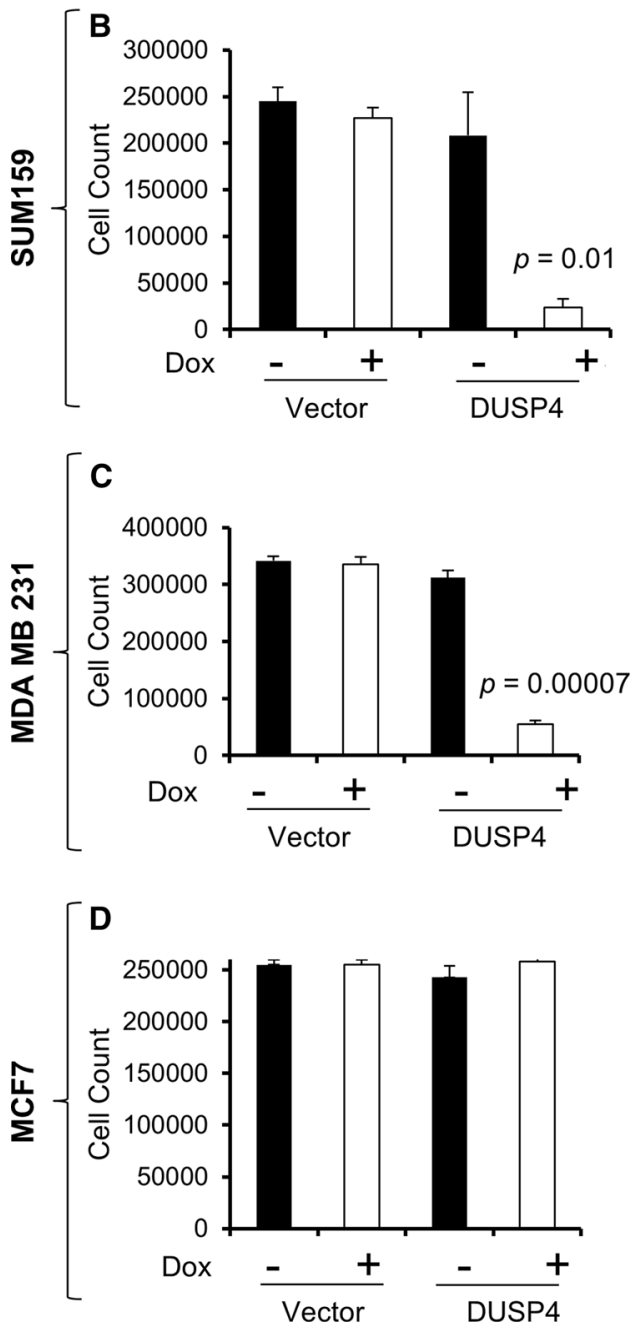

Anchorage-independent Growth

E

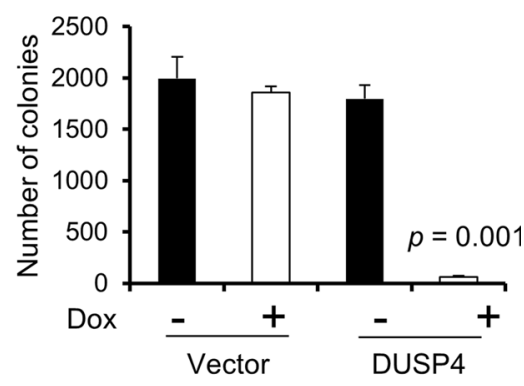

$\mathbf{F}$
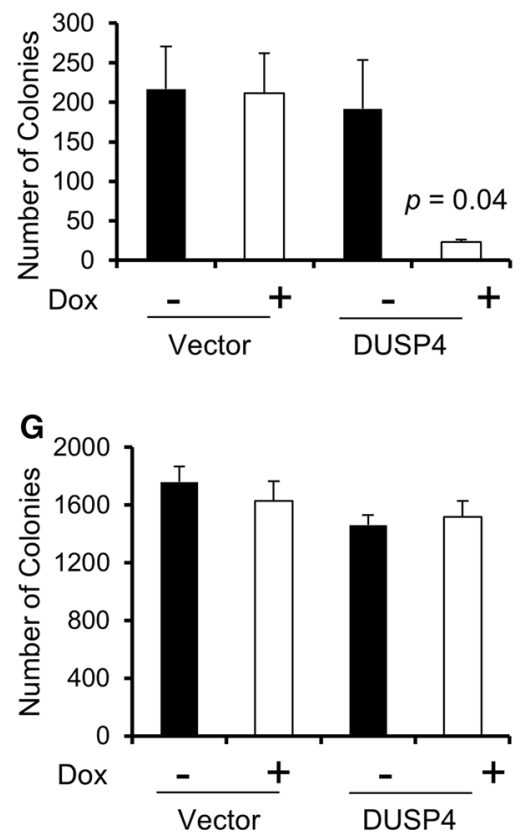

negative cells (Fig. 6a). DUSP4 overexpression significantly affects a number of differentially expressed proteins (Fig. 6a). The most commonly up-regulated and downregulated proteins are shown in Supplementary Table 2. Induced DUSP4 expression significantly alters expression of a number of signaling proteins, including several MAPK family members. Our RPPA results indicate DUSP4 expression significantly reduces phosphorylation of ERK1/ 2 at T202/204, p38 at T180/Y182, and JNK1 at T183/T185 (Fig. 6b). To confirm our RPPA results, we examined the effect of DUSP4 expression on phospho-ERK1/2, pJNK1, and phospho-p38 status by Western blot analysis. Our results indicate DUSP4 down-regulates ERK1/2, JNK1, and p38 signaling in both MDA-MB-231 and SUM 159 cells (Supplementary Figure 2). In addition, induced DUSP4 overexpression also affected other signaling proteins, resulting in significant inhibition of the phosphorylation of $\mathrm{Rb}$ (at S807/S811) and p65 (at S536), and increases AMPK phosphorylation (Fig. 6c). Collectively, these RPPA results suggest that DUSP4 induction significant impacts growth regulatory kinases (ERK1/2, JNK1, and p38) and downstream regulators of proliferation (p65 and $\mathrm{Rb}$ ), which directly or indirectly reduce tumor growth in ER-negative breast cancer cells. 
Fig. 4 Induction of DUSP4 expression inhibits the growth of ER-negative breast cancer cells in vivo. a Induced expression of DUSP4 does not inhibit in vivo xenograft growth of MDA-MB-231 vector clone \pm Dox; $\mathbf{b}$ calculated slope from MDA-MB-231 vector clone xenograft. c MDA-MB231-DUSP4 clone \pm Dox growth curves; $\mathbf{d}$ calculated slope from MDA-MB-231DUSP4 xenograft. e Induced expression of DUSP4 does not inhibit in vivo xenograft growth of SUM 159-Vector clone \pm Dox growth curves; f calculated slope from SUM 159-vector \pm Dox, g SUM 159-DUSP4 clone \pm Dox growth curves; $\mathbf{h}$ calculated slope from SUM 159-DUSP4 clone xenograft. $t$-test $p$ values are indicated
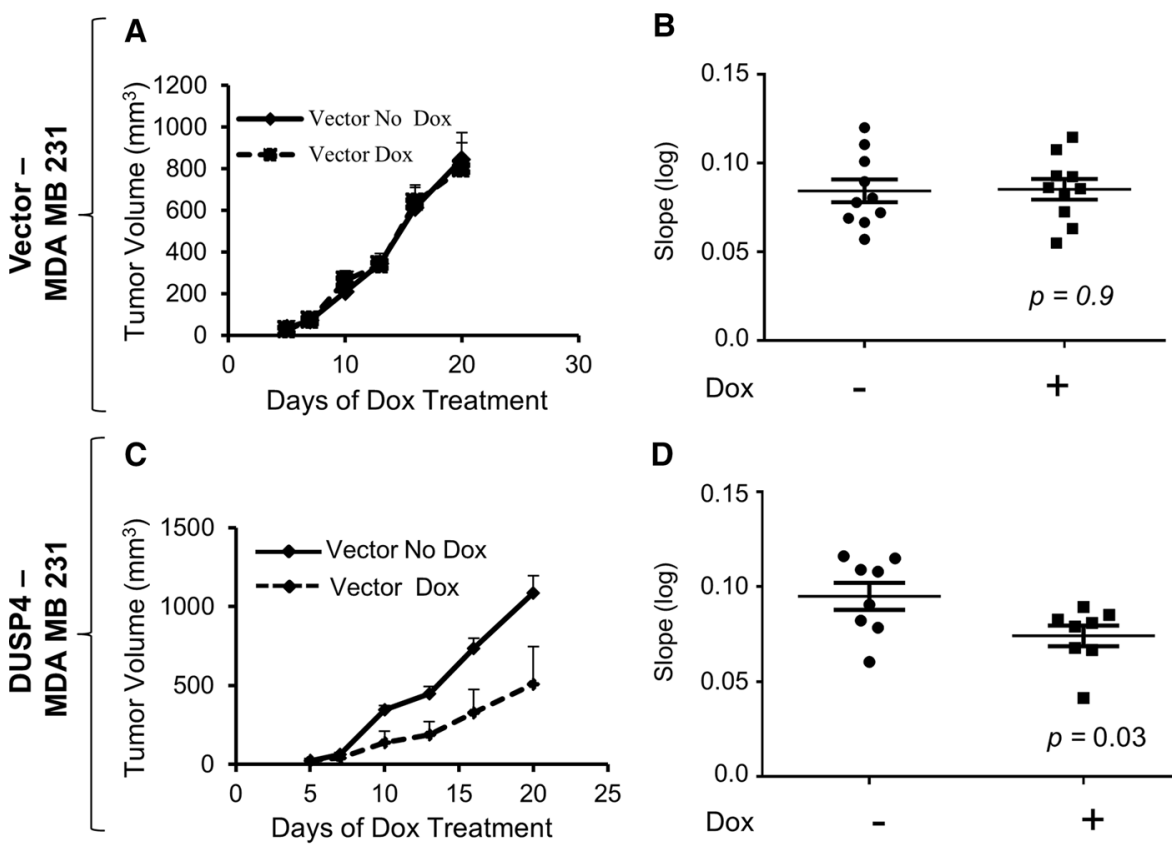

D
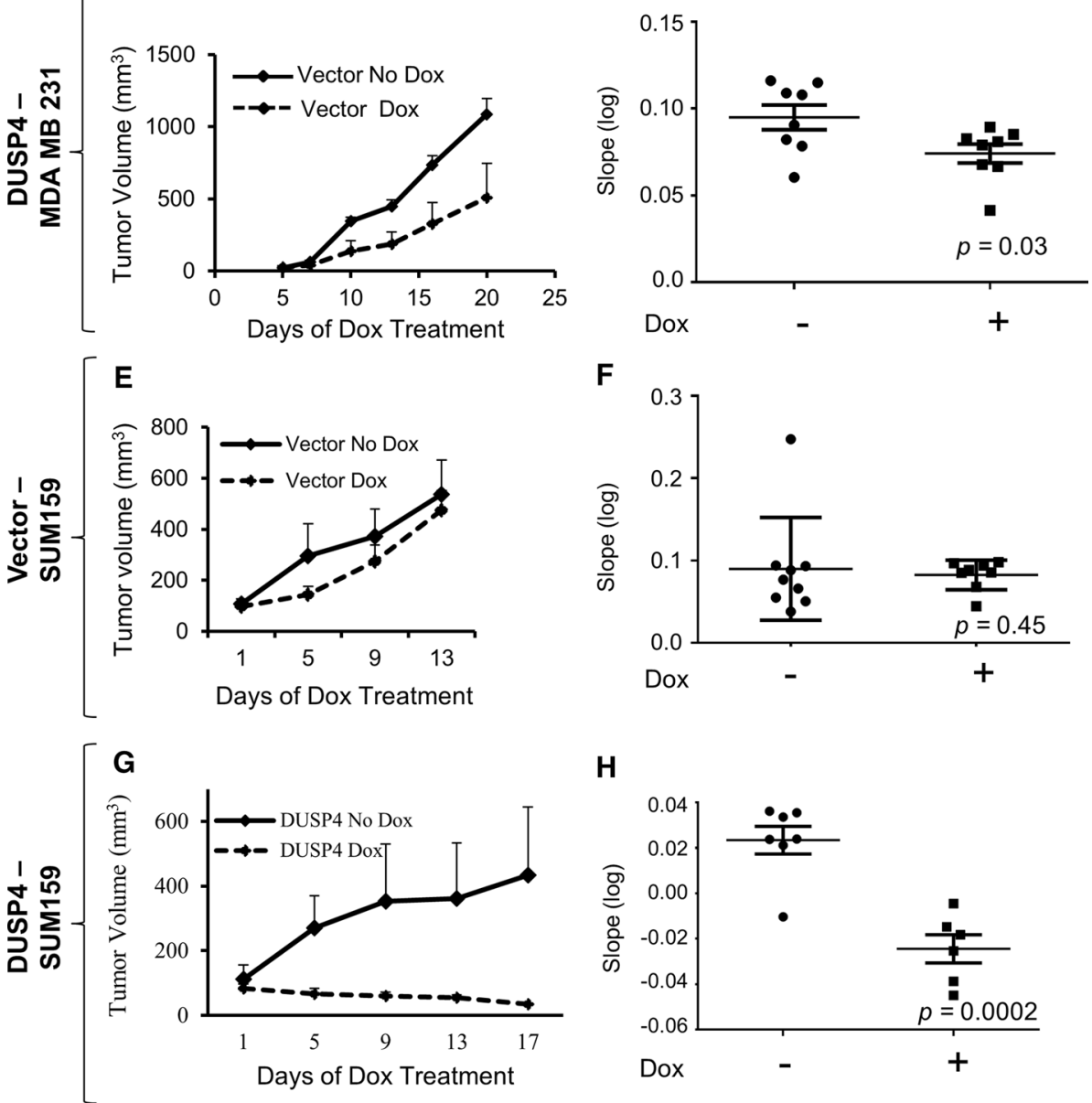

H

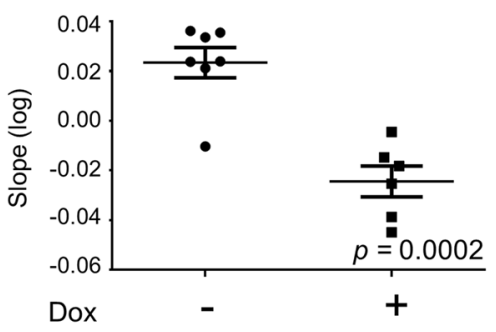

\section{Discussion}

In this study, we identified phosphatases differentially expressed in ER-negative compared to those in ER-positive breast cancers. We found 31 phosphatases significantly overexpressed and 11 phosphatases significantly underexpressed in ER-negative versus ER-positive breast cancers. Included in the set of underexpressed phosphatases are phosphatases regulating growth factor signaling pathways (INPP4B, PTPRT, and DUSP4), as well as phosphatases involved in gluconeogenesis (FPB1), nucleotide cleavage (ENPP1), and metabolism (CANT1). Of these 11 underexpressed phosphatases, DUSP4 is the most commonly deleted phosphatase, deleted in approximately $50 \%$ of human breast cancers. Our results show that DUSP4 overexpression in TNBCs suppresses breast cancer cell growth by suppression of MAPKs (ERK1/2, JNK1, and p38), NFkB, and Rb signaling pathways, ultimately causing a cell cycle block.

DUSP4 is an early response gene synthesized after growth factor stimulation [11, 32, 33] and has also been mapped to a gene locus that is frequently lost in breast and prostate cancer [34]. DUSP4 is localized in chromosome $8 \mathrm{p}$, part or all of which is commonly lost in multiple 
Fig. 5 Increased DUSP4 expression causes reduced proliferation, invasion, and a G1 cell cycle block.

a Representative Ki67 staining of MDA-MB-231 xenograft sections. b Quantitation of Ki67; c representative pictures of Boyden chamber assay for migration for the cells before and after DUSP4 induction. d Relative migration in MDAMB-231; e representative pictures of Boyden chamber assay for invasion for the cells before and after DUSP4 induction. $\mathbf{f}$ Relative invasion in MDA-MB-231. g Cell cycle changes after DUSP4 induction. $t$-test $p$ values are indicated
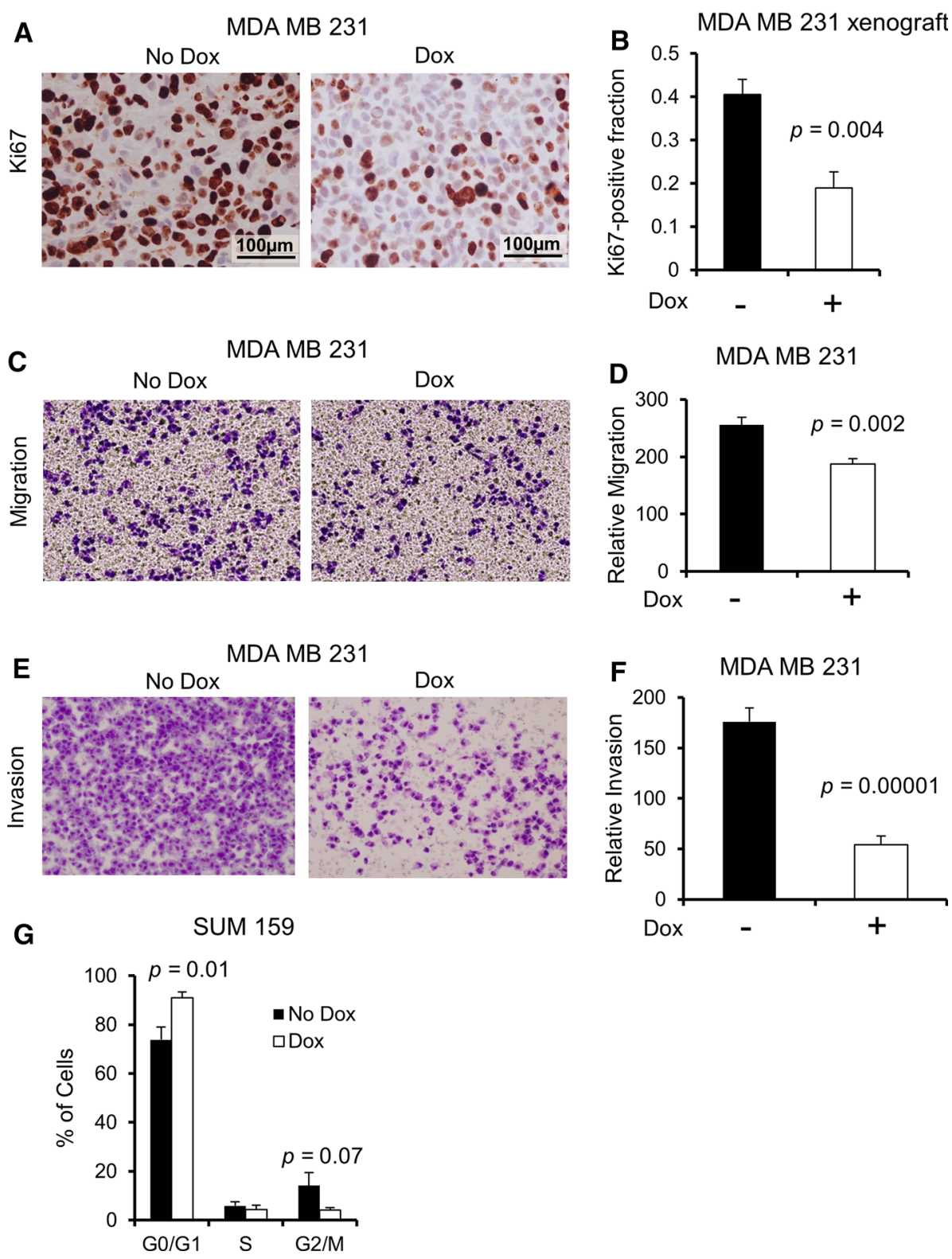

cancers including breast cancer [35-38]. Armes et al. [34] have shown loss of the DUSP4 gene and protein in earlyonset and high-grade breast cancer. DUSP4 loss or epigenetic silencing has been described in lung cancer and glioblastomas [15, 39, 40]. Re-expression of DUSP4 in lung cancer cells with $8 \mathrm{p}$ loss and low endogenous DUSP4 reduces growth, while knockdown of DUSP4 in cell lines with high DUSP4 expression enhances cell growth [15]. Our results are in agreement with these previously published studies [34, 40, 41]; together, our results and those of others suggest that DUSP4 is an important tumor suppressor gene in breast cancer.

Balko et al. have demonstrated that DUSP4 mRNA expression levels correlate inversely with MEK inhibitor sensitivity, suggesting that DUSP4 expression is a biomarker for MEK inhibitor sensitivity in PTEN-positive tumors $[16,42]$. Our results also show that DUSP4 inhibits ERK1/2 phosphorylation in TNBC cells, as well as p38 and JNK1/2 phosphorylation. Since termination of MAPK signaling is maintained by MAP phosphatases, lower expression of DUSP phosphatases results in increased MAPK activity [32, 43]. p38 has been shown to be involved in cell proliferation and tumorigenesis [44], and high levels of p38 in breast cancer patients correlates with invasiveness and poor prognosis [45]. Previously, we have shown that inhibition of the p38 kinase suppresses proliferation of ER-negative breast cancer cells [19]. Our present study suggests that inhibition of all three MAPKs by DUSP 
A

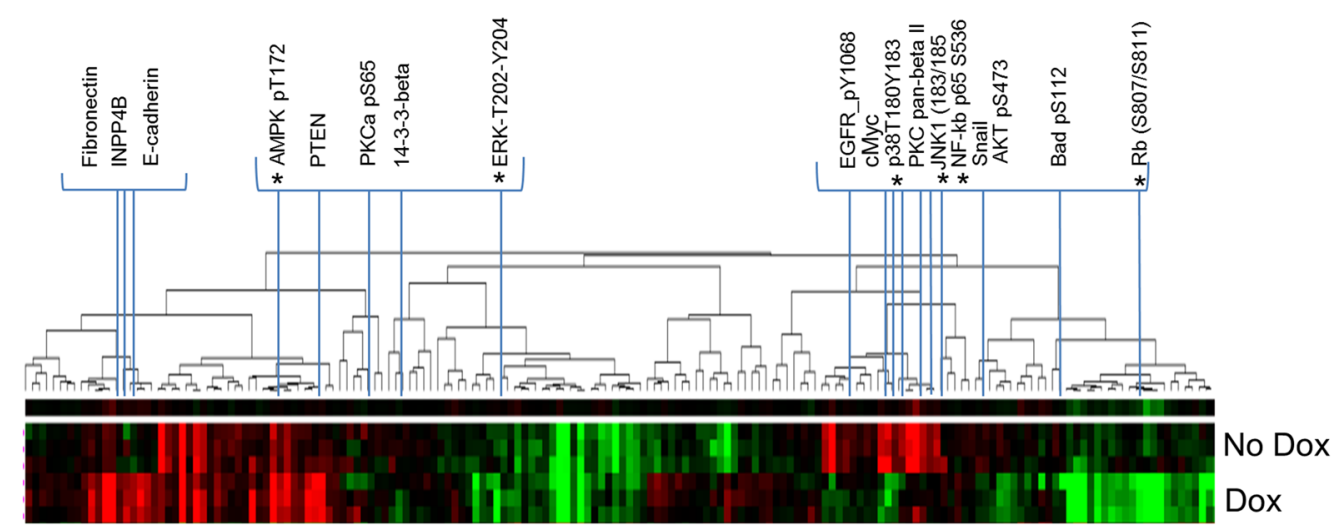

B

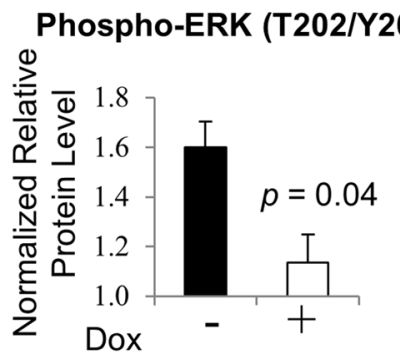

Phospho-p38 (T180/Y182)

Phospho JNK1 (T183/T185)

C
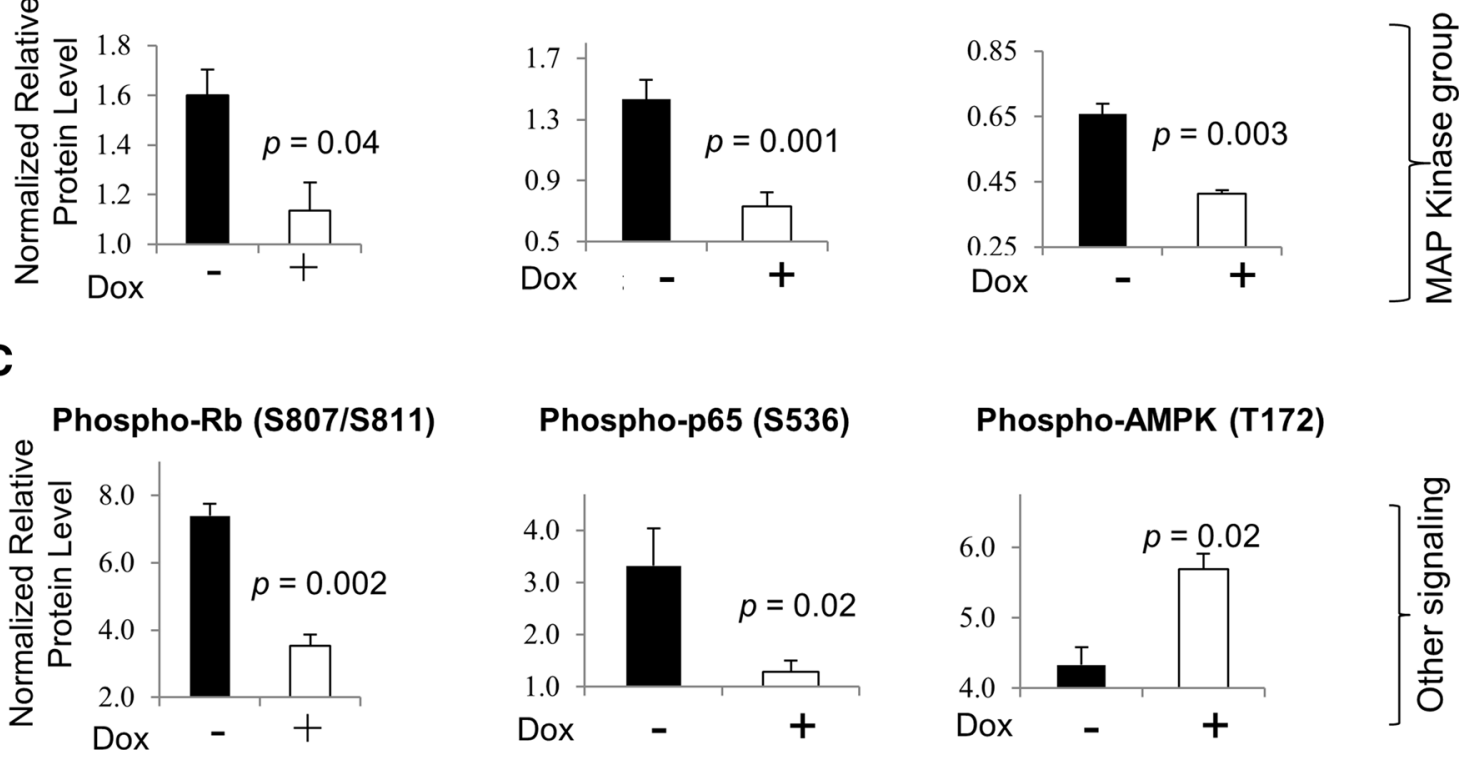

Phospho-p65 (S536)

Phospho-AMPK (T172)
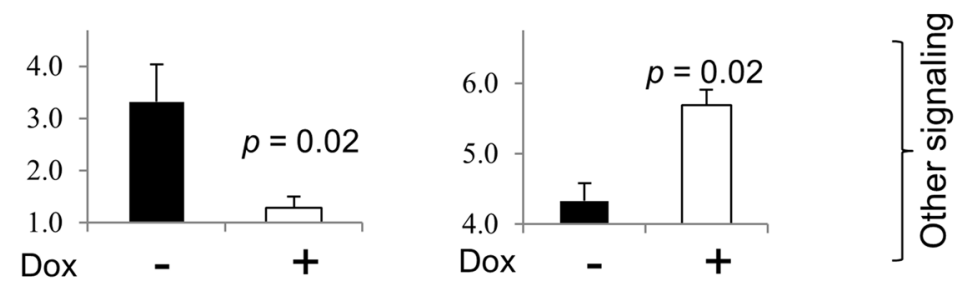

Fig. 6 RPPA analysis identifies signaling pathways altered upon induced expression of DUSP4. a RPPA analysis was performed on SUM159 cells with and without induction of DUSP4 $(-$ Dox $=$ No DUSP4 over expression and + Dox $=$ DUSP4 overexpression). Selective markedly altered proteins are indicated after DUSP4 expression. The median expression values for each protein in cells treated with

expression has a stronger growth inhibitory effect than inhibition of only ERK1/2 alone. Creighton et al. [46] previously demonstrated that increased MAPK activity causes loss of ER $\alpha$ expression and plays a role in the generation of the ER $\alpha$ phenotype. Our results suggest reduced expression of DUSP4 activates phosphorylation of all three MAPKs. Therefore, regulation of DUSP4 expression may influence the generation of ER $\alpha$-negative breast cancer via MAPK activation. Expression of DUSP4 also inhibits NFkB and Rb signaling, in addition to MAPK signaling, ultimately resulting in profound suppression of growth.

In this study, we demonstrated that several other phosphatases (PPP1R3C, INPP4B, FBP1, PTPRT, MTMR9,
Dox was subtracted from the protein expression value in cells treated with vehicle to obtain a difference value for each protein studied. Those proteins that showed the greatest change (increased or decreased) are shown in Supplementary Table 2. b Changes in MAP Kinase group: p-ERK1/2, p-p38, and p-JNK1/2. c Changes in the other signaling pathways: p-Rb, p-p65 (S536), and p-AMPK (T172)

and CANT1) are underexpressed in ER-negative compared to those in ER-positive breast cancers. The PPP1R3C gene is hypermethylated in colorectal cancer (CRC) [47], and is a candidate tumor suppressor gene in melanoma and is inactivated through promoter methylation [48]. Gewinner et al. have shown that INPP4B regulates the PI3 K pathway and that its gene is located in a region frequently deleted in both breast cancer cell lines and high-grade breast tumors [49-51]. Deletion of INPP4B has been shown to increase growth of breast cancer cells in vitro, and overexpression of INPP4B reduces growth in vivo [49]. Another phosphatase underexpressed in ER-negative breast cancer is FBP1. The FBP1 protein regulates glycolysis and epithelial-to-mesenchymal transition in breast cells, and 
overexpression of FBP1 reduces growth of breast cancer cells [52]. The other phosphatases we identified as underexpressed in ER-negative breast cancer (PTPRT, MTMR9, CANT1, ENPP1, and CILP) may play important roles in signal transduction and tumorigenesis in breast as well as other cancers. Thus, this approach of examining the differential expression of phosphatase genes in ER-positive and ER-negative breast cancer has identified many important phosphatases that regulate tumor growth and tumorigenesis.

Through this genomic study of RNA from human breast cancers, we identified specific phosphatases differentially expressed in ER-negative breast cancers compared to those in ER-positive breast cancers. For this study, we focused on those phosphatases underexpressed in ER-negative versus ER-positive breast cancer. Such phosphatases may be important tumor suppressor genes in ER-negative breast cancer. We also demonstrated that DUSP4 controls the growth and invasiveness of ERnegative breast cancer, and alters the phosphorylation of several growth-promoting signaling proteins, including three MAPKs (ERK, p38, and JNK) and NFkB. These results suggest that targeting this pathway by targeting the downstream genes ERK, p38, JNK, and NFאB, or by reactivating DUSP4 (possibly by using demethylation agents), provides a novel approach for the treatment of ER-negative, and particularly triple-negative, breast cancer.

Acknowledgments We would like to thank Michelle Savage for editing the manuscript and Sam Short for assisting in the submission.

\section{Compliance with ethical standards}

Conflict of interest PH Brown is on the Scientific Advisory Board of Susan G. Komen for the Cure. All the remaining authors declare no actual, potential, or perceived conflict of interest that would prejudice the impartiality of this article.

Financial support This work was funded by two NCI Cancer Center Support Grants (P30CA125123, A.T., S.G.H., S.F., C.K.O; and P30CA016672, P.H.B., G.B.M.), an NIH SPORE grant (P50 CA58183, C.K.O.), an NCI P01 grant (P01CA0099031, G.B.M.), the Biostatistics and Informatics Shared Resource (Baylor College of Medicine), a breast SPORE grant (BCM CCSG-CA125123, C.K.O.), a Susan G Komen Promise Grant (KG081694 P.H.B., G.B.M.), a Komen SAC grant (SAC110052, G.B.M.), and a Komen SAB grant (KG081694, P.H.B.).

Open Access This article is distributed under the terms of the Creative Commons Attribution-NonCommercial 4.0 International License (http://creativecommons.org/licenses/by-nc/4.0/), which permits any noncommercial use, distribution, and reproduction in any medium, provided you give appropriate credit to the original author(s) and the source, provide a link to the Creative Commons license, and indicate if changes were made.

\section{References}

1. Siegel R, Ma J, Zou Z, Jemal A (2014) Cancer statistics. CA Cancer J Clin 64(1):9-29

2. Dowsett M, Cuzick J, Ingle J, Coates A, Forbes J, Bliss J, Buyse M, Baum M, Buzdar A, Colleoni M, Coombes C, Snowdon C, Gnant M, Jakesz R, Kaufmann M, Boccardo F, Godwin J, Davies C, Peto R (2010) Meta-analysis of breast cancer outcomes in adjuvant trials of aromatase inhibitors versus tamoxifen. J Clin Oncol 28(3):509-518

3. Jakesz R, Jonat W, Gnant M, Mittlboeck M, Greil R, Tausch C, Hilfrich J, Kwasny W, Menzel C, Samonigg H, Seifert M, Gademann G, Kaufmann M, Wolfgang J (2005) Switching of postmenopausal women with endocrine-responsive early breast cancer to anastrozole after 2 years' adjuvant tamoxifen: combined results of ABCSG trial 8 and ARNO 95 trial. Lancet 366(9484):455-462

4. Mouridsen H, Giobbie-Hurder A, Goldhirsch A, Thurlimann B, Paridaens R, Smith I, Mauriac L, Forbes J, Price KN, Regan MM, Gelber RD, Coates AS (2009) Letrozole therapy alone or in sequence with tamoxifen in women with breast cancer. N Engl J Med 361(8):766-776

5. Cuzick J, Sestak I, Baum M, Buzdar A, Howell A, Dowsett M, Forbes JF (2010) Effect of anastrozole and tamoxifen as adjuvant treatment for early-stage breast cancer: 10-year analysis of the ATAC trial. Lancet Oncol 11(12):1135-1141

6. Cuzick J, Sestak I, Forbes JF, Dowsett M, Knox J, Cawthorn S, Saunders C, Roche N, Mansel RE, von Minckwitz G, Bonanni B, Palva T, Howell A (2014) Anastrozole for prevention of breast cancer in high-risk postmenopausal women (IBIS-II): an international, double-blind, randomised placebo-controlled trial. Lancet 383(9922): 1040

7. Tan AR, Swain SM (2001) Adjuvant chemotherapy for breast cancer: an update. Semin Oncol 28(4):359-376

8. Baselga J, Bradbury I, Eidtmann H, Di Cosimo S, de Azambuja E, Aura C, Gomez H, Dinh P, Fauria K, Van Dooren V, Aktan G, Goldhirsch A, Chang TW, Horvath Z, Coccia-Portugal M, Domont J, Tseng LM, Kunz G, Sohn JH, Semiglazov V, Lerzo G, Palacova M, Probachai V, Pusztai L, Untch M, Gelber RD, Piccart-Gebhart M, Neo AST (2012) Lapatinib with trastuzumab for HER2-positive early breast cancer (NeoALTTO): a randomised, open-label, multicentre, phase 3 trial. Lancet 379(9816):633-640

9. Geyer CE, Forster J, Lindquist D, Chan S, Romieu CG, Pienkowski T, Jagiello-Gruszfeld A, Crown J, Chan A, Kaufman B, Skarlos D, Campone M, Davidson N, Berger M, Oliva C, Rubin SD, Stein S, Cameron D (2006) Lapatinib plus capecitabine for HER2-positive advanced breast cancer. $N$ Engl J Med 355(26):2733-2743

10. Speers C, Tsimelzon A, Sexton K, Herrick AM, Gutierrez C, Culhane A, Quackenbush J, Hilsenbeck S, Chang J, Brown P (2009) Identification of novel kinase targets for the treatment of estrogen receptor-negative breast cancer. Clin Cancer Res 15(20):6327-6340

11. Robinson CJ, Sloss CM, Plevin R (2001) Inactivation of JNK activity by mitogen-activated protein kinase phosphatase- 2 in EAhy926 endothelial cells is dependent upon agonist-specific JNK translocation to the nucleus. Cell Signal 13(1):29-41

12. Chu Y, Solski PA, Khosravi-Far R, Der CJ, Kelly K (1996) The mitogen-activated protein kinase phosphatases PAC1, MKP-1, and MKP-2 have unique substrate specificities and reduced activity in vivo toward the ERK2 sevenmaker mutation. J Biol Chem 271(11):6497-6501 
13. Chen P, Hutter D, Yang X, Gorospe M, Davis RJ, Liu Y (2001) Discordance between the binding affinity of mitogen-activated protein kinase subfamily members for MAP kinase phosphatase-2 and their ability to activate the phosphatase catalytically. J Biol Chem 276(31):29440-29449

14. Tresini M, Lorenzini A, Torres C, Cristofalo VJ (2007) Modulation of replicative senescence of diploid human cells by nuclear ERK signaling. J Biol Chem 282(6):4136-4151

15. Chitale D, Gong Y, Taylor BS, Broderick S, Brennan C, Somwar R, Golas B, Wang L, Motoi N, Szoke J, Reinersman JM, Major J, Sander C, Seshan VE, Zakowski MF, Rusch V, Pao W, Gerald W, Ladanyi M (2009) An integrated genomic analysis of lung cancer reveals loss of DUSP4 in EGFR-mutant tumors. Oncogene 28(31):2773-2783

16. Balko JM, Cook RS, Vaught DB, Kuba MG, Miller TW, Bhola NE, Sanders ME, Granja-Ingram NM, Smith JJ, Meszoely IM, Salter J, Dowsett M, Stemke-Hale K, Gonzalez-Angulo AM, Mills GB, Pinto JA, Gomez HL, Arteaga CL (2012) Profiling of residual breast cancers after neoadjuvant chemotherapy identifies DUSP4 deficiency as a mechanism of drug resistance. Nat Med 18(7):1052-1059

17. Romano P, Manniello A, Aresu O, Armento M, Cesaro M, Parodi B (2009) Cell line data base: structure and recent improvements towards molecular authentication of human cell lines. Nucleic Acids Res 37:D925-D932

18. Hartman ZC, Poage GM, den Hollander P, Tsimelzon A, Hill J, Panupinthu N, Zhang Y, Mazumdar A, Hilsenbeck SG, Mills GB, Brown PH (2013) Growth of triple-negative breast cancer cells relies upon coordinate autocrine expression of the proinflammatory cytokines IL-6 and IL-8. Cancer Res 73(11):3470-3480

19. Chen L, Mayer JA, Krisko TI, Speers CW, Wang T, Hilsenbeck SG, Brown PH (2009) Inhibition of the p38 kinase suppresses the proliferation of human ER-negative breast cancer cells. Cancer Res 69(23):8853-8861

20. Gao J, Aksoy BA, Dogrusoz U, Dresdner G, Gross B, Sumer SO, Sun Y, Jacobsen A, Sinha R, Larsson E, Cerami E, Sander C, Schultz N (2013) Integrative analysis of complex cancer genomics and clinical profiles using the cBioPortal. Sci Signal 6(269):pl1

21. Cerami E, Gao J, Dogrusoz U, Gross BE, Sumer SO, Aksoy BA, Jacobsen A, Byrne CJ, Heuer ML, Larsson E, Antipin Y, Reva B, Goldberg AP, Sander C, Schultz N (2012) The cBio cancer genomics portal: an open platform for exploring multidimensional cancer genomics data. Cancer Discov 2(5):401-404

22. VandeVijver MJ, He YD, van't Veer LJ, Dai H, Hart AA, Voskuil DW, Schreiber GJ, Peterse JL, Roberts C, Marton MJ, Parrish M, Atsma D, Witteveen A, Glas A, Delahaye L, vander Velde T, Bartelink H, Rodenhuis S, Rutgers ET, Friend SH, Bernards R (2002) A gene-expression signature as a predictor of survival in breast cancer. N Engl J Med 347(25):1999-2009

23. Desmedt C, Piette F, Loi S, Wang Y, Lallemand F, Haibe-Kains B, Viale G, Delorenzi M, Zhang Y, d'Assignies MS, Bergh J, Lidereau R, Ellis P, Harris AL, Klijn JG, Foekens JA, Cardoso F, Piccart MJ, Buyse M, Sotiriou C (2007) Strong time dependence of the 76-gene prognostic signature for node-negative breast cancer patients in the TRANSBIG multicenter independent validation series. Clin Cancer Res 13(11):3207-3214

24. Kao KJ, Chang KM, Hsu HC, Huang AT (2011) Correlation of microarray-based breast cancer molecular subtypes and clinical outcomes: implications for treatment optimization. BMC Cancer 11:143

25. Chin K, DeVries S, Fridlyand J, Spellman PT, Roydasgupta R, Kuo WL, Lapuk A, Neve RM, Qian Z, Ryder T, Chen F, Feiler H, Tokuyasu T, Kingsley C, Dairkee S, Meng Z, Chew K, Pinkel D, Jain A, Ljung BM, Esserman L, Albertson DG, Waldman FM,
Gray JW (2006) Genomic and transcriptional aberrations linked to breast cancer pathophysiologies. Cancer Cell 10(6):529-541

26. Wang Y, Klijn JG, Zhang Y, Sieuwerts AM, Look MP, Yang F, Talantov D, Timmermans M, Meijer-van Gelder ME, Yu J, Jatkoe T, Berns EM, Atkins D, Foekens JA (2005) Gene-expression profiles to predict distant metastasis of lymph-node-negative primary breast cancer. Lancet 365(9460):671-679

27. Minn AJ, Gupta GP, Siegel PM, Bos PD, Shu W, Giri DD, Viale A, Olshen AB, Gerald WL, Massague J (2005) Genes that mediate breast cancer metastasis to lung. Nature 436(7050): $518-524$

28. Saal LH, Johansson P, Holm K, Gruvberger-Saal SK, She QB, Maurer M, Koujak S, Ferrando AA, Malmstrom P, Memeo L, Isola J, Bendahl PO, Rosen N, Hibshoosh H, Ringner M, Borg A, Parsons R (2007) Poor prognosis in carcinoma is associated with a gene expression signature of aberrant PTEN tumor suppressor pathway activity. Proc Natl Acad Sci USA 104(18):7564-7569

29. Curtis C, Shah SP, Chin SF, Turashvili G, Rueda OM, Dunning MJ, Speed D, Lynch AG, Samarajiwa S, Yuan Y, Graf S, Ha G, Haffari G, Bashashati A, Russell R, McKinney S, Group M, Langerod A, Green A, Provenzano E, Wishart G, Pinder S, Watson P, Markowetz F, Murphy L, Ellis I, Purushotham A, Borresen-Dale AL, Brenton JD, Tavare S, Caldas C, Caldas C, Aparicio S (2012) The genomic and transcriptomic architecture of 2,000 breast tumours reveals novel subgroups. Nature 486(7403):346-352

30. Lu X, Lu X, Wang ZC, Iglehart JD, Zhang X, Richardson AL (2008) Predicting features of breast cancer with gene expression patterns. Breast Cancer Res Treat 108(2):191-201

31. Hatzis C, Pusztai L, Valero V, Booser DJ, Esserman L, Lluch A, Vidaurre T, Holmes F, Souchon E, Wang H, Martin M, Cotrina J, Gomez H, Hubbard R, Chacon JI, Ferrer-Lozano J, Dyer R, Buxton M, Gong Y, Wu Y, Ibrahim N, Andreopoulou E, Ueno NT, Hunt K, Yang W, Nazario A, DeMichele A, O'Shaughnessy J, Hortobagyi GN, Symmans WF (2011) A genomic predictor of response and survival following taxane-anthracycline chemotherapy for invasive breast cancer. JAMA 305(18):1873-1881

32. Amit I, Citri A, Shay T, Lu Y, Katz M, Zhang F, Tarcic G, Siwak D, Lahad J, Jacob-Hirsch J, Amariglio N, Vaisman N, Segal E, Rechavi G, Alon U, Mills GB, Domany E, Yarden Y (2007) A module of negative feedback regulators defines growth factor signaling. Nat Genet 39(4):503-512

33. Hirsch DD, Stork PJ (1997) Mitogen-activated protein kinase phosphatases inactivate stress-activated protein kinase pathways in vivo. J Biol Chem 272(7):4568-4575

34. Armes JE, Hammet F, de Silva M, Ciciulla J, Ramus SJ, Soo WK, Mahoney A, Yarovaya N, Henderson MA, Gish K, Hutchins AM, Price GR, Venter DJ (2004) Candidate tumor-suppressor genes on chromosome arm $8 \mathrm{p}$ in early-onset and high-grade breast cancers. Oncogene 23(33):5697-5702

35. Radford DM, Fair KL, Phillips NJ, Ritter JH, Steinbrueck T, Holt MS, Donis-Keller H (1995) Allelotyping of ductal carcinoma in situ of the breast: deletion of loci on 8p, 13q, 16q, 17p and 17q. Cancer Res 55(15):3399-3405

36. Thor AD, Eng C, Devries S, Paterakos M, Watkin WG, Edgerton S, Moore DH 2nd, Etzell J, Waldman FM (2002) Invasive micropapillary carcinoma of the breast is associated with chromosome 8 abnormalities detected by comparative genomic hybridization. Hum Pathol 33(6):628-631

37. Yokota T, Yoshimoto M, Akiyama F, Sakamoto G, Kasumi F, Nakamura Y, Emi M (1999) Localization of a tumor suppressor gene associated with the progression of human breast carcinoma within a 1-cM interval of 8p22-p23.1. Cancer 85(2):447-452

38. Adams J, Cuthbert-Heavens D, Bass S, Knowles MA (2005) Infrequent mutation of TRAIL receptor 2 (TRAIL-R2/DR5) in 
transitional cell carcinoma of the bladder with $8 \mathrm{p} 21$ loss of heterozygosity. Cancer Lett 220(2):137-144

39. Britson JS, Barton F, Balko JM, Black EP (2009) Deregulation of DUSP activity in EGFR-mutant lung cancer cell lines contributes to sustained ERK1/2 signaling. Biochem Biophys Res Commun 390(3):849-854

40. Waha A, Felsberg J, Hartmann W, von dem Knesebeck A, Mikeska T, Joos S, Wolter M, Koch A, Yan PS, Endl E, Wiestler OD, Reifenberger G, Pietsch T (2010) Epigenetic downregulation of mitogen-activated protein kinase phosphatase MKP-2 relieves its growth suppressive activity in glioma cells. Cancer Res 70(4):1689-1699

41. Venter DJ, Ramus SJ, Hammet FM, de Silva M, Hutchins AM, Petrovic V, Price G, Armes JE (2005) Complex CGH alterations on chromosome arm $8 \mathrm{p}$ at candidate tumor suppressor gene loci in breast cancer cell lines. Cancer Genet Cytogenet 160(2):134-140

42. Balko JM, Schwarz LJ, Bhola NE, Kurupi R, Owens P, Miller TW, Gomez H, Cook RS, Arteaga CL (2013) Activation of MAPK pathways due to DUSP4 loss promotes cancer stem celllike phenotypes in basal-like breast cancer. Cancer Res 73(20):6346-6358

43. Camps M, Nichols A, Arkinstall S (2000) Dual specificity phosphatases: a gene family for control of MAP kinase function. FASEB J 14(1):6-16

44. Bulavin DV, Higashimoto Y, Popoff IJ, Gaarde WA, Basrur V, Potapova O, Appella E, Fornace AJ Jr (2001) Initiation of a G2/M checkpoint after ultraviolet radiation requires p38 kinase. Nature 411(6833):102-107

45. Gutierrez MC, Detre S, Johnston S, Mohsin SK, Shou J, Allred DC, Schiff R, Osborne CK, Dowsett M (2005) Molecular changes in tamoxifen-resistant breast cancer: relationship between estrogen receptor, HER-2, and p38 mitogen-activated protein kinase. J Clin Oncol 23(11):2469-2476
46. Creighton CJ, Hilger AM, Murthy S, Rae JM, Chinnaiyan AM, El-Ashry D (2006) Activation of mitogen-activated protein kinase in estrogen receptor alpha-positive breast cancer cells in vitro induces an in vivo molecular phenotype of estrogen receptor alpha-negative human breast tumors. Cancer Res 66(7):3903-3911

47. Takane K, Midorikawa Y, Yagi K, Sakai A, Aburatani H, Takayama T, Kaneda A (2014) Aberrant promoter methylation of PPP1R3C and EFHD1 in plasma of colorectal cancer patients. Cancer Med 3(5):1235-1245

48. Bonazzi VF, Irwin D, Hayward NK (2009) Identification of candidate tumor suppressor genes inactivated by promoter methylation in melanoma. Genes Chromosomes Cancer 48(1):10-21

49. Gewinner C, Wang ZC, Richardson A, Teruya-Feldstein J, Etemadmoghadam D, Bowtell D, Barretina J, Lin WM, Rameh L, Salmena L, Pandolfi PP, Cantley LC (2009) Evidence that inositol polyphosphate 4-phosphatase type II is a tumor suppressor that inhibits PI3 K signaling. Cancer Cell 16(2):115-125

50. Chin SF, Wang Y, Thorne NP, Teschendorff AE, Pinder SE, Vias M, Naderi A, Roberts I, Barbosa-Morais NL, Garcia MJ, Iyer NG, Kranjac T, Robertson JF, Aparicio S, Tavare S, Ellis I, Brenton JD, Caldas C (2007) Using array-comparative genomic hybridization to define molecular portraits of primary breast cancers. Oncogene 26(13):1959-1970

51. Naylor TL, Greshock J, Wang Y, Colligon T, Yu QC, Clemmer V, Zaks TZ, Weber BL (2005) High resolution genomic analysis of sporadic breast cancer using array-based comparative genomic hybridization. Breast Cancer Res 7(6):R1186-R1198

52. Dong C, Yuan T, Wu Y, Wang Y, Fan TW, Miriyala S, Lin Y, Yao J, Shi J, Kang T, Lorkiewicz P, St Clair D, Hung MC, Evers BM, Zhou BP (2013) Loss of FBP1 by snail-mediated repression provides metabolic advantages in basal-like breast cancer. Cancer Cell 23(3):316-331 